\title{
Shopping and Working in the Borderlands: \\ Article Enforcement, Surveillance and Marketing in Tijuana, Mexico
}

\section{Magalí Murià}

University of California, San Diego, USA.

mmuria@dssmail.ucsd.edu

\section{Sergio Chávez}

Rice University, USA.

sergio.chavez@rice.edu

\begin{abstract}
This article examines how border enforcement at the U.S.-Mexico border affects the border crossing and consumption practices of Tijuana residents. Drawing on three years of combined ethnographic research, we focus on the experiences of Tijuana residents who cross the international border with legal documents to work and consume in the United States. We argue that the technologies of surveillance and deterrence that regulate cross-border transit also reshape the geographical and social landscape of Tijuana. We explain how identities and patterns of difference among border residents are reconstructed by a legal taxonomy that identifies and classifies crossers according to categories of legality. We find that these categories are locally framed and translated into a binary distinction between consumers and workers that reflect a growing gap between the rich and poor in the city. Finally, we conclude that this distinction ignores the transnational character of the city, and in particular, that consumers and workers are not mutually exclusive categories at the borderlands.
\end{abstract}

\section{Introduction}

In this article, we explain how border enforcement and surveillance in the Tijuana-San Diego region reorganize the mobility of local populations whose livelihoods are defined by cross-border social and economic activities. We discuss how residents of the southern side of the U.S.-Mexico border interpret, incorporate, and negotiate border controls that re-shape the space where they live, work, and consume. In a historical period marked by closure and openness, the U.S. government has simultaneously engaged in border policing while facilitating free trade. This contradiction re-structures social relations, identities and differences, not only across the international fence, but also within Mexican border cities. To fit into local systems of cultural meanings (Engle Merry 2006, 1), we argue that once categories of difference cross the border into Tijuana, classification standards that U.S. authorities use to identify, control, and discipline border crossers are locally reframed into a binary distinction between consumers and workers.

This categorization becomes problematic in a region marked by intense cross-border trade where consumption and labour practices are not mutually exclusive. We argue that splitting these activities produces patterns of social and spatial segregation that manifest in Tijuana's urban landscape, with targeted marketing strategies and highly differentiated housing developments. We base our argument on three years of combined field research in Tijuana. We bring together our observations and in-depth interviews to study crossing strategies and consumption practices in contemporary Tijuana. Although we 
both initially began with a different empirical focus, we realize that we cannot understand consumption without production and vice versa, especially in a border context with frequent social and economic transactions. We trace the everyday experiences of border residents as they move from one country to another as both consumers and workers.

To date, most studies on border enforcement have focused on policies to deter clandestine crossings, and in particular, the role of border patrol agents with sophisticated technology to capture and deport unauthorized crossers (Cornelius 2005; Andreas 2000; Nevins 2002). By the same token, literature that reports on the experience of border crossers concentrate on labour migrants who travel without U.S. inspection (Singer and Massey 1998; Donato et al. 2008; Gathmann 2008; Spener 2009). Although these works highlight the effects of increased surveillance on undocumented border crossings, border enforcement does not only affect clandestine transit, but also other forms of cross-border economic and social activities that this research has not addressed. Studies that discuss the move from geo-politics to bio-politics (see for instance Van der Ploeg 2006; Amoore 2006 and 2007; Muller 2004; Ackleson 2000, and 2003) are useful in framing the disciplinary effect of a tightened border security on the everyday lives for those who legally cross the ports of entry. Since both consumption and work practices sustain everyday life, we consider it relevant to study the effect of these border policies and technologies on the conditions of existence (Bourdieu 1980, 56) for those who have a long-term habit of crossing the border frequently for work and shopping purposes. So what happens when border policies of territorial control cross the border and land in a socially polarized society like Tijuana? In the following section, we address these uneven dynamics by providing a brief overview of the cross-border activities among residents in Tijuana, Mexico.

\section{Double-Edged Integration: Crossing the border to Shop and Work}

"Shopping?" The immigration agent asked a wealthy Mexican lady with an expensive SUV, as she crossed from Tijuana to San Diego. "Sure", she responded reluctantly and became irritated by the immigration officer's question. She had left her home in an exclusive Tijuana neighbourhood to conduct business in San Diego, California. Her job was based in Mexico, but it required meeting people across the border. She worked for one of the hundreds of institutions, corporations and agencies that operate on a cross-border basis. She became irritated with the officer because she was insulted that just because she looked a certain way and drove a good car, she was assumed to cross the border to shop. "They are making me look like the soccer mom I struggle not to become..." she confided. "And I said yes, first, because I don't want to get into trouble if I explain what I do, and second, because I was actually planning to stop by an organic farmers market to buy lettuces on the way back [to Mexico]". This conversation illustrates one way in which Tijuana residents have learned to negotiate their mobility in an era of increased surveillance. In particular, the woman's reflection illustrates how border crossers must reconstruct their identity to conform to the border crossing rules established by the U.S. government, and not the binational economy. The complexities of their everyday economic and social life have to be reduced to clear, readable and simple intentions in order to negotiate daily life in a region where ambiguity is considered a threat (Muller 2008, 208).

During our ethnography, we asked local residents about their travel experiences to San Diego, or as they colloquially say "cruzar al otro lado" (go the other side). As part of the study, we investigated people's most common reasons to cross (or not cross) the border, the obstacles they encountered while doing it, and how these obstacles affected their relations to U.S. inspection officials and other residents. We found a variety of answers to these questions; not surprising considering that Tijuana-San Diego is the busiest international Port of Entry in the western hemisphere. Roughly 57 million people cross the border northbound every year, and while most media attention focuses on illegal activities (such as drug and human trafficking), 97 percent of crossings from Tijuana to San Diego are legal and occur through the Port of Entry (San Diego Dialogue 1994, i). Economic studies have consistently shown that among local 
populations, the most common purposes for crossing the Tijuana-San Diego border are visiting relatives, shopping, and working (see San Diego Dialogue 1994, and Ghoddar and Brown 2005b).

In 2008, Mexican shoppers spent \$6 billion in San Diego's economy. Historically, San Diego has benefited from a market of Mexican foreign consumers who boost local retail sales and sales tax revenues. These Mexican customers tend to pay cash and rarely return products purchased in the U.S. People from Tijuana also attend movies, patronize restaurants, listen to concerts, and visit theme parks. Some even go to private schools (see Crossborder Business Associates (CBA) 2004; Martínez 2006; Ghoddar and Brown 2005a; 2005b). In the past, people also crossed the border for simple household tasks such as washing clothes, as if it were a routine part of their day, because Tijuana's hard water damaged washing machines and clothes.

The habit of crossing the border to shop in the U.S. is deeply ingrained in the consumer culture of Tijuana's local residents. Historically, Tijuana's infrastructure and economic ties to the interior of Mexico were weak and the city was more integrated to the northern side of the border than to Mexican production hubs. Consumer goods from the south were scarce and expensive, and Mexican consumers often complained that the quality was not on par with those purchased in San Diego. In 1932, Tijuana's economic disconnect from the rest of Mexico motivated the Mexican government to create a free trade zone, where the importation of foreign products for personal use was allowed. Since then, the practice of crossing to 'the other side' for consumption purposes has survived for generations. In a combination of tourism and everyday errands, people sometimes prefer to purchase groceries, clothes, school supplies, auto parts and so on in San Diego. We interviewed, for instance, residents who crossed the international border to take advantage of milk sales in San Ysidro, California stores. Throughout most of the twentieth century, this pattern of transnational consumption crystallized in a material culture that both expressed and produced a hybrid identity and a strong integration between cities on both sides of the border. At one time, Tijuanans' ability to engage in cross-border activities differentiated them from other Mexicans, and old timers from recent immigrants.

Not only do Tijuana residents contribute to San Diego's economy through consumption, but also with their transnational labour practices. Each day, some 30,000 to 50,000 people cross legally to work in neighbouring San Diego County (Alegria 2002; Rubin-Kurtzman et al. 1996; Herzog 1990). Some crossers are eligible for employment in the United States, because they hold work visas, Green Cards or U.S. passports. Others cross the border with documents that do not allow them to work, like tourist visas, which has turned this form of border commuting into a suspicious activity (Rubin-Kurtzman et al. 1996) and, since the attacks of September 11, 2001, crossing the border to work without proper documents has been placed under the same category as terrorism (see for instance Amoore 2006). Those who do not possess legal documents to work in the U.S. must convince immigration officials that they are crossing to shop and not for employment purposes. For those who do not have U.S. citizenship or Legal Permanent Residency, the possibility of working in the U.S. is subject to strict criteria of eligibility, as well as long and costly procedures to approve job permits. However, thousands of commuters live in Tijuana and work in San Diego (with and without proper documents) because cross-border labour offers the advantage of making a wage in U.S. dollars while spending it in Mexican Pesos, which inevitably represents a boost in the standard of living and social status (see Acuña 1988; Martínez 1994). Cross-border Mexican workers earn as much as 19 percent of all wages in Tijuana (Rubin-Kurtzman et al. 1996, 1035).

The practice of working across the border has deep historic roots in Tijuana. This labour market strategy became institutionalized from 1942 to 1964 when Mexico and the U.S. jointly agreed to the Bracero Agreement that mitigated agricultural labour shortages produced by the war effort. Tijuana became a permanent destination for many return migrants. Rather than settle in the U.S. or engage in seasonal migration as others had done, they brought their families with them and established roots in Tijuana. The braceros lived in Tijuana and commuted to labour in the agricultural fields of San Diego County on a 
daily and weekly basis. After the Agreement ended, these workers were encouraged by their San Diego employers to settle in Tijuana. In fact, the border patrol allowed them to circulate freely even if they did not possess legal documents to cross into San Diego as long as they remained within proximity of the U.S.-Mexico border (Chávez 2007). The Bracero Agreement started a trend that did not end with its termination in 1964. People continued migrating as U.S. employers provided them with jobs. In an effort to incorporate return migrants into the national economy, the Mexican government started a series of economic development programmes which increased industrial activity in northern Mexico ${ }^{1}$, including the establishment of maquiladoras and other incentives for industries to establish themselves in Tijuana. These newly created jobs increased migration waves into the region of both domestic and international migrants. For this reason, Tijuana is a city that has grown at an accelerated pace (Fussell 2004; INEGI 2000; Rubin-Kurtzman et al. 1996). In 2000, the Mexican Census found that almost half of Tijuana's population was comprised of residents born in other parts of Mexico (Chávez 2007, 88; Rubin-Kurtzman et al. 1996).

\begin{tabular}{|c|c|}
\hline \multicolumn{2}{|c|}{ Tijuana's Population Since 1900 } \\
\hline 1900 & 245 \\
\hline 1910 & 733 \\
\hline 1920 & 1,028 \\
\hline 1930 & 1,526 \\
\hline 1940 & 21077 \\
\hline 1950 & 32751 \\
\hline 1960 & 165,690 \\
\hline 1970 & 340,583 \\
\hline 1980 & 461,257 \\
\hline 1990 & $1,110,140$ \\
\hline 2005 & $1,483,992$ \\
\hline
\end{tabular}

Table 1

(Source: INEGI, 2005)

These two historical trends, the habit to consume across the border and the proclivity to work on 'the other side', integrate the economies of these twin border cities. In Tijuana, people attempt to take advantage of what they refer to as 'the best of both worlds' by crossing the border to earn higher U.S. wages and lower overall costs for U.S. consumer goods. By living in the borderlands, they can work in the U.S. and take advantage of cheaper housing costs in Tijuana. At the end of the day, both consumers and workers return home from the U.S., but only one of these activities, shopping, continues to be encouraged by U.S. authorities. In contrast, those who are suspected or known to work without proper documents in the U.S. are subject to severe penalties that range from deportation to incarceration ${ }^{2}$. Even those who cross the border to work legally are often questioned extensively for living a life of ambiguity, residence in Mexico but employment in the U.S. Crossing for the purpose of consumption vs. production differentiate the legal shopper from the illegal worker. In other words, in the contemporary period of increased border surveillance, Mexicans are embraced as consumers but excluded as workers.

\footnotetext{
${ }^{1}$ In 1965 the Mexican government launched the National Border Program (PRONAF, for its Spanish acronym) and in 1965 the Border Industrialization Program (PIF, for its Spanish acronym).

2 In 1996 IIRIRA (acronym for Illegal Immigration Reform and Immigrant Responsibility Act), increased at the federal level civil penalties for illegal entry, taking serious steps in criminalizing unauthorized immigration, even making it, in some cases, subject to incarceration. IIRIRA also reduced the rights of those subject to apprehension, as it prohibited federally financed legal services to bring class action suits against immigration authorities on behalf of illegal immigrants (De Laet 2000, 127).
} 
As we will demonstrate in the remaining pages, the binary consumer/worker has become a common way to locally reframe other classification criteria U.S. authorities use to determine who is threatening and who is not (Amoore 2006, 337), who is a friend and who is an enemy (Muller 2004, 280). We also argue that, as these classification schemes become integrated into everyday life in Tijuana, the difference between 'legitimate mobilities' versus 'illegitimate mobilities' (Amoore 2006, 339), translates into a more extended regime of spatial and social segregation based on class and race differences, a scenario where selected peoples and areas keep their global connections, expressed in this case by cross-border mobility, while others remain disconnected (see Borja and Castells 1997; Graham and Marvin 2001; Caldeira 2000). In the section that follows, we explain how this difference is constructed and filtered in the context of the U.S.-Mexico border.

\section{Consuming and Working: Border Enforcement in a Borderless Economy}

Traditionally, international borders are spaces where the modern state exerts the power of sovereignty (see for instance Tuathail 2000; Hastings and Donnan 1999; Sorensen 2004.) This explains the fact that measures to control and regulate cross-border movement in Tijuana-San Diego started taking place since the border itself was defined in 1847, after the end of the Mexican-American War. Historically, the most visible manifestations of state power have left their imprint on the landscape and the territory, with the construction of walls, fences and gates, making it relevant to talk about the expressions of this power across space or territoriality (see Sack 1992; Delaney 2005; Paasi 1996; 1999). However, we must not limit conceptualizations of territoriality only to land and territory. By delimiting and asserting control over a geographical area, we must not overlook that fact that territoriality also permeates into people's behaviour and social relations as it affects, influences, and regulates "people, phenomena, and relationships" (Sack 1992, 92). It is also involved in the "creation, circulation and interpretation of meaning" (Delaney 2005, 16), and therefore influences identity and social difference. For these reasons, we argue here that territory at the U.S.-Mexico border is used as an agent of control, spatial ordering, and social sorting (Lyon 2005; Lewis 2005).

In Tijuana and San Diego, state territoriality has increasingly regulated people's lives, re-organized social relations, and re-attached meaning to cross-border mobilities, making it possible for governments to manage and discipline local populations. Physically, the U.S. government exerts territorial control through the construction of walls, fences and other material infrastructures that have visibly re-shaped the border landscape. Legally, it does so with the enactment of legislation that restricts cross-border mobility and classifies border crossers according to their individual standing with U.S. immigration law. After the 9/11 attacks, territoriality materialized into a technology-based system that combines goals of deterrence of unwanted crossers and surveillance of all cross-border travellers. This system of control has been named the 'biometric border', which consists of implementing "scientific technologies and managerial expertise in the politics of border management; and the exercise of biopower such that the bodies of migrants and travelers themselves become sites of multiple encoded boundaries" (Amoore 2006, 336; see also Muller 2008).

Since 1929, Mexican nationals residing in Tijuana were required to carry documents to cross through the Port of Entry. However, when the Port of Entry was first established, travelling to San Diego and crossing the international border were not scrutinized, controlled, and regulated the way it is today. It was, as many old residents repeatedly said in our interviews, 'a natural thing to do', invested with a sense of immediacy; an act that one did not need to plan in advance, to quickly go to the other side to pour gas, buy milk or do laundry. Several migrants that we interviewed remembered that, as late as the 1980s, Tijuana residents were allowed to cross the border even if they had forgotten their documents at home, so long as they knew the immigration official at the gate. One local Tijuana resident who worked as a pharmacist near the Port of Entry explained that he was allowed to enter the U.S. to purchase hamburgers when he wore his Pharmacist uniform, even though he did not have documents to travel. The 'other side', particularly the 
cities of Chula Vista and San Ysidro located next door to the U.S.-Mexico border, was historically part of the living space of border residents, perceived to be an extension of Tijuana. However, territorial policies gradually 'denaturalized' the practice of border crossings, and people in Tijuana adjusted to growing cross-border transit restrictions.

By 1969, Operation Intercept gave local residents a sense that the U.S. federal authorities became more intrusive in their everyday life. Intercept institutionalized inspection and in the process, slowed the transit of vehicles and people crossing through the ports of entry. One of the practices most affected at the time was laundry services. In San Ysidro, laundry mats lost 60 to 90 percent of their revenue (Proffitt 1988, 47). In 1986, the Immigration Reform and Control Act marked a major shift in how the U.S. government began to curtail undocumented migration. IRCA increased the presence of the border patrol, it introduced employer sanctions, and it also made it a crime for employers to hire undocumented workers. In 1993, Operation Gatekeeper continued to transform how the U.S. government policed its borders by placing walls and other physical barriers across the international line. One year later, in 1994, Mexico and the United States celebrated the North American Free Trade Agreement (NAFTA), which dramatically increased the transit of people, trucks, and vehicles through the ports of entry ${ }^{3}$.

In Tijuana-San Diego, as well as in the rest of the border, NAFTA showed its face in contradictory ways, because the increase in trade came accompanied by a boost to border enforcement (Nevins 2002; Andreas 1996). This led to the "simultaneous creation of a barricaded border and a borderless economy" (Andreas 2000, x), which put local populations at a crossroads between opposing forces of openness and closure. This is not exclusive to the border. It illustrates a global process in which trans-boundary flows are intensifying the contradiction between two key functions of the modern state: boundary enforcement and trans-boundary economic development (see Nevins 2000, 106-108). In this context, controlling border crossings became a strategic site for the U.S. government to retain the exercise of sovereignty, while abdicating to denationalizing forces in other areas like trade and investment (Pickering and Weber 2006, 22). These contradictions are also explained by the creation of two parallel regimes, one for the circulation of capital and another for the circulation of immigrants (Sassen 1996). As we will discuss below, these two regimes translate in the context of the border into differences among local residents that manifest socially and spatially in Tijuana's urban landscape.

In the new era of global economic integration, U.S. border authorities faced a dual contradictory challenge of 'enforcement and facilitation': enforcement at the border to prevent the smuggling of undesired products and people, and facilitation of trade, business and leisure travellers such as businessmen, tourists and shoppers. This was not an easy task. Because Tijuana's residents have historically circulated backand-forth, they had a sense of entitlement over the space where they lived and shared the feeling that U.S. federal agents were foreign to the region and did not understand its social and economic relations. During the time we conducted research at the Tijuana-San Diego border, we observed exasperated agents attempt to classify border crossers. When an immigration official asked where they came from, they often got a clear but vague response: "from here". As a result, immigration officials had to ask more precisely "where where you born", and pressure people to narrow down their answer: "San Diego", or "Minneapolis", or "Beirut, Lebanon", in which case the person would be asked to provide proof of citizenship or legal residence. These questions allowed immigration officials to effectively discern who was a desirable and undesirable crosser.

\footnotetext{
3 The tremendous increase in bilateral trade (from $\$ 55.2$ billion in 1989 to $\$ 266$ billion in 2004) greatly affected the border region: By 2004, 69 percent of the value of the NAFTA merchandise trade was carried across the common border by truck (Ganster and Lorey 2008, 190). Accordingly, the number of $20 \mathrm{ft}$ containers entering U.S. border crossings doubled between 1990 and 2000 (Ackleson 2003, 64). Particularly in the California-Baja California border, the impact was huge: between 1995 and 2004 the number of trucks crossing into the United States through the ports of entry increased by 167 percent (Ganster and Lorey 2008, 190).
} 
However, to determine whether a person would engage in approved activities given their border crossing status was more difficult. During our ethnography, we learned from so many cases such as Ana María Salazar, a Tijuana-born 20 year old who was arrested and deported after mistakenly handing a border agent her Community College ID by accident, along with a tourist visa. Ana Maria returned a few hours later to the gate and crossed without problems, by falsely declaring in perfect English that she was a U.S. citizen. After the ordeal she commented, "Who were those strangers [referring to immigration officials], after all, to determine what I could do and could not in San Diego, if I had lived in the region my whole life?" And more importantly, how could they decipher on which side of the line she was born, if she dressed, spoke and acted like an American? Practices of cross-border mobility have helped maintain the hybrid character of the borderlander, making it difficult for authorities to accurately identify border populations. Bodies that are not readable inevitably challenge the ability of states to identify persons of 'their own' from others (Torpey 2000; Muller 2008). To this dilemma, the solution was found by establishing a highly selective system, operated through the application of high-end technologies and a legal framework that would enable the individual identification of people.

In the late 1990s, the U.S. State Department established stricter eligibility standards to cross to "the other side' by replacing the old Border Crossing Cards with a Laser Visa. The Laser Visas are machine readable, credit-card-sized documents with digitally encoded biometric data, including a photograph and fingerprints. Unlike other Mexican citizens, border residents could previously use an entirely different document, called the INS I-187 Border Crossing Card (BCC), commonly known as 'Mica'. According to regulations established by the Immigration and Naturalization Service (INS) which later became the Department of Homeland Security, these cards were issued "for the convenience of our Mexican neighbors for such activities as shopping or visiting relatives within the international frontier area of the United States" (INS in Martis 1970,14). It took about a year of residence in Tijuana to become eligible for a BCC, and only residence and employment in Baja California were required to apply (Musbach 1980, 2). The Mica allowed free movement on the U.S. side of the border within 25 miles for up to 72 hours, with the only restriction that its holders were forbidden to accept U.S. employment. People could obtain them at the port of entry. Children 14 years and under could cross with their mother as long as their name was listed in the card (Martis 1970).

Territoriality involves the regulation of movement, and the legitimate means of movement depends on identifying people accurately. To maintain the "legitimate monopoly of movement" (Torpey 2000), governments seek to unambiguously determine people's identities (Torpey, 2000; Nevins 2002). People are classified according to taxonomies, which according to Donna Haraway operate as "little machines for classifying and separating categories" (cited in Star and Bowker 1999, 202). Managing the border then includes using a taxonomy, or a classificatory system, that attaches identities to individuals according to categories of legality, or standards adjudicated by U.S. law that are contingent on place of birth, citizenship or legal status. Changing the micas or BCCs for the Laser Visas facilitated the classification and identification of every individual that crosses the border in Tijuana. The biometric technologies embedded in the document provide a full picture of a crosser's biography in relation to the spectrum of U.S. immigration law. The Laser Visa facilitates the organization of individuals across space, according to an orderly grid where people stay where they belong (Shields 1991, 39).

At the same time, territoriality also rests on the interconnection between space and behaviour (Sack 1986, 25), which brings us to consider the relevance of discipline in this process. Discipline, argued Foucault, was never more valorized than at the moment of managing populations. In his words: "The notion of a government of population renders all the more acute the problem of the foundation of sovereignty and all the more acute equally the necessity for the development of discipline" (Foucault 1991, 95). Surveillance disciplines people (Van der Ploeg 2006, 192) and biometric technologies provide the technical tools to read off the body, crucial in the task of controlling movement. These technologies enhance the disciplinary power of U.S. immigration authorities by facilitating the identification of border crossers, 
which in turn helps determine spatial attributions according to the rank or place a person occupies in this classification. In other words, they make it easier for border agents to sort border crossers and make sure that do not engage in unauthorized activities once on 'the other side'.

Nowadays, nearly half of border crossers hold Laser Visas (Ghoddar and Brown 2005a, 46). Unlike BCCs that did not expire, these documents last 10 years. Laser Visas are for individual use only and the eligibility standards to obtain one are now the same for all Mexican citizens. This de facto eliminated the exceptional treatment that border residents previously enjoyed. The State Department mandated that

laser visa applicants must meet the same eligibility standards as those for the B1/B2 visa ${ }^{4}$. Applicants must demonstrate that they have ties to Mexico that would compel them to return after a temporary stay in the U.S. Consular officers look for evidence of strong family, business, or social ties. (U.S. Department of State 2008)

Needless to say, some of the parameters used to determine 'family, businesses or social ties' are hard to fulfill in Tijuana, since families are often spread on both sides of the line, as are social and business networks. Then, the notion of 'ties to Mexico' is often interpreted in terms of economic affluence, or a secure source of income that decreases the risk that the person will use the card to work illegally. In fact, many applicants who are denied visas in Tijuana are seldom told that the reason for the denial is that they will establish themselves illegally in the U.S., but that they will use the document "to work". Binary categories such as 'citizen-alien', 'friend-enemy', 'migrant-tourist', 'legal-illegal' (see Muller 2004; Wonders 2006) locally translate as they cross the border as 'consumer-worker'.

With the terrorist attacks of September 11, 2001, and the birth of the Department of Homeland Security, there was a dramatic increase in the number of Border Patrol agents, and a budget increase to border security, reaching a total of $\$ 7$ billion in 2006 (Payan 2006). In January of 2002, the Bush administration launched Smart Borders, designed to screen for terrorist incursions at U.S. air and land Ports of Entry. By and large, Smart Borders implemented new surveillance technologies, an exit-tracking system to monitor the arrival and departure of non-citizens, and the use of 'enhanced border inspection': additional inspectors, canine teams, and x-ray machines to screen people entering by land and what they considered 'high risk cargo'. In practical terms, Smart Borders refined and perfected the selective border that accompanied NAFTA. Regarding this, President George W. Bush stated that Smart Borders posed "little or no obstacle to the legitimate trade and travel...(while) keep(ing) pace with expanding trade while protecting the United States from the threats of terrorist attacks, illegal immigration, illegal drugs, and other contraband" (Bush quoted in Ackleson 2003, 64). Smart Borders further intensified the employment of cutting edge technology to enhance the dual capabilities of 'enforcement and facilitation'. On a more pragmatic level, the use of technologies such as biometrics and inter-linked information technology databases became instrumental to "identify problematic entrants - either persons or cargo (e.g., terrorists and their weapons) -while at the same time facilitating the quick entry of legitimate goods and travelers" (Ackleson 2003, 57).

Usually, biometric data gathered in crossing documents and at the moment of crossing the border is linked to databases that store information about individuals that can be accessed by various government agencies. This is the case, for instance, of US-VISIT, a system that screens all foreign visitors, which is now available at U.S. consular offices overseas, airports and some ports of entry, including San Ysidro and Otay Mesa in the Tijuana-San Diego border. Upon arrival, people are subjected to digital finger scans and photographs that are collected and analyzed. However, border crossers ignore which information authorities have of every individual, which data is considered relevant, or which is not. The crosser cannot

${ }^{4}$ B1/B2 Visas are documents that allowed foreign nationals to visit the United States as tourists. Employment is not permitted with these cards. 
share the view of the screen that informs the agent about his/her status. In the absence of accurate information, people in Tijuana share rumours and anecdotes, which reinforce the lack of transparency. Ports of Entry have also installed tracking mechanisms to collect data on vehicles and people entering and leaving the country, such as licence plates readers, to help determine patterns of movement. Evidence on individuals crossing at specific crossing hours can help indicate a violation of U.S. law. For example, if the movement of an individual with a Laser Visa is tracked entering northwards every morning, government officials can use this data to conclude that the person is entering to work without authorization. These devices provide evidence against people whose visas, Green Cards or citizenship applications are being processed. For instance, Green Card holders are authorized for work in the United States but they are restricted from living abroad ${ }^{5}$. This legislation does not contemplate the regional character of border cities, as it establishes a clear-cut distinction between residing in U.S. territory and living in another country. At the border, many of these Green Card holders spend nights and weekends in the southern side and cross the border to work during the day. Photographs taken at the moment of crossing have been used as evidence to deny these crossers U.S. citizenship.

People cross the border for a variety of reasons, in many cases as part of a daily routine to attend school, work, and shop. While doing so, some actually violate the attributions conceded to them by the type of entry document they hold. If they were crossing to shop, then they should be prepared to show credit cards and be able to name the stores where they will make purchases. Additionally, if a person was unlawfully working in the U.S. then they should not be caught carrying evidence that shows their ties to U.S. employers whether it be a work uniform or paystubs (see for example Hernandez-Leon 2008; Heyman 2009; Chavez forthcoming). To discern violators from potential terrorists, and criminals from 'everyday crossers', there is an increasing standardization of procedures that blur the boundaries between threatening activities and practices of everyday life. Accordingly, every person who goes through the port of entry seems now to be considered guilty until she or he demonstrates her or himself to be innocent (Payan 2006, 110).

In fact, the technologies of control that have been implemented to regulate cross-border movement invest the sole act of crossing the border with a connotation of illegality, which justifies the close monitoring of all individuals, consumers and workers, without distinction. Marketing strategies sometimes capitalize on the blurring of boundaries between illegality and everyday life, even suggesting an explicit marriage between frivolity and violence, with a halo of erotic brutality. An example of this connection was contained on a bill-board advertising an expensive clothing store outlet, with the image of a young male model naked from the waist up, and the words "Feel free to search us". The ad hung next to the U.S. government facilities where detainees were held sometimes without accountability 6 . This particular billboard did not last long. A couple of weeks later it was replaced by another one, with the suggestive text "We just wanted to sneak this in" but with no image (see figure 1).

U.S. immigration agents have the mission of facilitating legal crossings while deterring unauthorized substances and people. Both documents and bodies are then read and sorted to determine who is in violation of U.S. law. People's identities are rearranged according to categories that distinguish citizens from aliens, legals from illegals, permanent residents from tourists and so on. In Foucauldian terms, "the human body enters here the spatial machinery of power that explores it, breaks it down and rearranges it"

\footnotetext{
5 According to the U.S. Citizenship and Immigration Services, a "Green Card" holder or Legal Permanent Resident must reside continuously in the United States to maintain their legal status. A person who lives permanently in Mexico or resides for an extended period of time without re-entry can have their legal status revoked. See http://www.uscis.gov/portal/site/uscis under "Green Card."

${ }^{6}$ According to U.S. law, the border is considered an "inspection zone". People entering the U.S. are expected to first go through the inspection zone before having access to the rest of the territory. In this zone, people can be detained and interrogated without a court order and certain rights related to personal integrity are subordinated to imperatives of national security and territorial sovereignty.
} 
(Foucault, quoted in Shields 1991, 40). However, for those who readily cross the border, these categories translate into stereotypes informed by the way a person dresses, looks, or moves (Payan 2006). Touching upon issues of gender, race and class, these stereotypes influence who is perceived to cross to consume, and who is instead, presumably doing it to work without authorization. However, even if the former is encouraged while the latter is frowned upon, the boundaries between these two activities are often blurry, because, sometimes, people who cross the border to work also shop, and vice versa. They are, after all, overlapping categories of crossers.

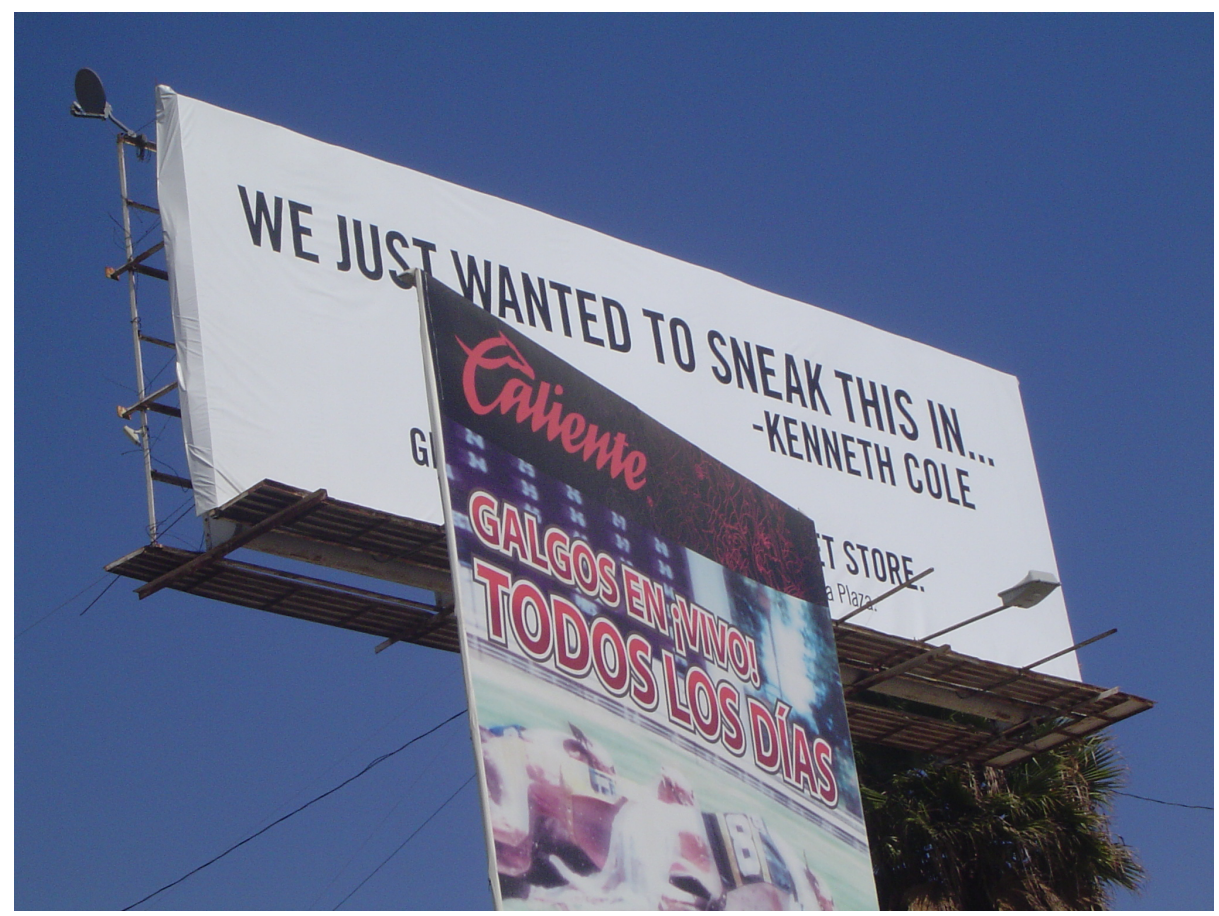

\section{Figure 1}

Marketing at the San Ysidro Port of Entry

People in Tijuana tend to assess their chances of obtaining a visa, and being able to cross the border without being harassed, as a function of how wealthy they look and also, the colour of their skin. Heyman (2009), for example, finds that working-class Mexicans as opposed to middle-class Mexicans, who are fairer in skin, are more likely to be questioned extensively by immigration officials and denied entry. He finds that even Mexican American immigration officials are more likely to scrutinize fellow Mexicans (Heyman 2002). According to this logic, it is likely that the affluent European-looking lady like the one we mentioned earlier, who drives a new expensive S.U.V., manufactured in Mexico, with licence plates of Baja California will be branded as a consumer, while an indigenous looking man, driving an old imported car, with border licence plates, will more likely be taken for a worker, and thus scrutinized more closely? In a similar fashion, the city's residents regularly circulate stories about the ambiguity and irregularity of border crossing experiences, like the case of a young student with accentuated indigenous features, who attended a local university. Because he was consistently targeted by U.S. inspectors every time he crossed through the Port of Entry, he and his peers joked that no one wanted to ride with him whenever they crossed the border to attend a concert or patronize a bar. His sole presence would, in this case, automatically trigger delays, additional interrogations, and very possibly, an inconvenient stop at secondary inspection. In other instances, friends of darker skin colour were designated to the back seat of the car where they were less likely to be seen by immigration officials. At all costs, border crossers want

\footnotetext{
7 According to Mexican Customs Laws, border residents can import a U.S. purchased vehicle after paying an importation fee to the Mexican government. The vehicle must be at least 10 years old and in good working condition. In Tijuana, driving a vehicle with a 'Baja California' licence plate can signify a higher social status because the person possibly purchased the vehicle in Mexico at a higher rate.
} 
to avoid secondary inspection where they are more likely to be questioned extensively and asked to generate documents and proof that they are crossing for legal reasons.

People crossing the border then share a constant fear of arbitrariness, because it is hard to predict when an inspector decides who poses a risk. In fact, the lack of transparency of their standards, criteria and procedures, turns surveillance technologies into the tip of an iceberg, the visible fragment of an invisible system of control, a virtual infrastructure that occasionally becomes evident, when it is used against particular individuals. We interviewed, for instance, people who have seen their visas revoked for reasons as strange as carrying a Starbucks receipt, because the agent saw it as evidence that the crosser may be holding an illegal job. At this point, the vast array of high end technological devises, biometric cards, sensors and databases, seem to be combined with the visual discrimination agents conduct in their daily routines:

Whether trying to keep people out or helping them come in, border officials must rely heavily on strategies like race and class profiling, and individualized conceptions of risk and harm when doing their jobs. While these policies are not officially sanctioned, the impetus for such profiling remains strong" (Wonders 2006, 80).

Crossers are constantly screened by cameras, licence plate readers and even toxic substance sensors. These technological devises capture crossing patterns, but in the end, they are subjectively interpreted by immigration officials, and also border crossers themselves.

\section{Visual discrimination, niche marketing and databases in Tijuana}

Parallel to the surveillance mechanisms that control and regulate border crossings, there are, in Tijuana, market research and marketing activities that can help understand the ways in which classification categories like the consumer-worker distinction operate in the region. In other words, marketers practice forms of inclusion and exclusion based on the desirability of people who cross to shop in the U.S. in a manner similar to those that occur at border crossings. Every Thursday, a selected number of Tijuana residents who are identified as 'shoppers' by local marketers receive at their doorstep El Cupon de la Semana or The Weekly Coupon, a package that contains discount coupons to San Diego stores, and advertisements about sales and deals. Each package has a code bar, which is used by San Diego businesses like Macy's, Sears and Target to track useful information about those using the coupons: demographic data is vital, but so too is the Tijuana neighbourhood where a shopper resides. Very relevant is the form of payment, credit or cash. This indicates, among other things, if the person is a resident or a citizen of the U.S (and therefore eligible for credit) or if he or she enters the country with a laser visa, possibly earning a wage in Mexican pesos. Different consumer profiles are also determined by the day the purchase was made. Consumers who shop on the weekends or late at night, are more likely to have full-time employment in Tijuana, and are therefore unable to cross the border during regular business hours, when the wait is significantly shorter. Those who buy during the week tend to be people with enough time and money to make a trip across the border at more convenient times: either affluent housewives or individuals who work on the U.S. side. The marketing approaches by these corporations operate on similar principles to the U.S. government in that they target populations that are desirable for San Diego's consumer market.

Cross-border marketing is not new at the border, and it is not uncommon to find advertising of products and stores in Tijuana's old newspapers. A study conducted in a local newspaper found that, between 1959 and 2005, San Diego businesses paid for 6.7 percent of the advertising. Most of them were supermarkets, retail, toy, jewellery and thrift stores (Murià and Chávez 2006). In the 1980s, local planners decided to build large shopping centres in southern San Diego, next to the freeways that connect to Tijuana, taking into account the importance of the Mexican consumer. At that time, those establishments would not have 
survived exclusively with U.S. clientele, which did not have the income to support such large businesses. Mexican consumers made a big difference; they guaranteed the expected profit for these massive investments to succeed. Today, as restrictions to cross the border have multiplied, people think twice before embarking in a shopping adventure. According to the San Diego Association of Governments (SANDAG), delays at the border result in losses to the local economy amounting to $\$ 6$ billion, producing the loss of 51,325 jobs (SANDAG 2006, vii). At the same time, the proportion of people who are not allowed to cross the border is increasing, posing a challenge for U.S. marketers to detect which consumers should be included in their campaigns and which ones should be excluded from advertisement activities.

The Weekly coupon delivers 150,000 coupon packages every week. There are warehouses on both sides of the border where they assemble the product, and prepare it for distribution. The last stop in Tijuana is a large garage located in an industrial park where the packets are placed into all-wheel drive vehicles, each of them with an assigned route. The incomparable efficiency of this business resides on the ability to penetrate the chaotic urban landscape of Tijuana, and still reach the correct customers: households whose members have the habit of crossing the border to shop. Surveys, software, census, and databases have a limited impact in most of these areas because there is a marked social heterogeneity (Alegría 2006). In the older neighbourhoods, built before 1990, it is common to see affluent residences next to shacks, which makes urban landscapes in Tijuana as hard to discern as border crossers. In an interview with the owner of El Cupón, we found that it takes a combination of skill and knowledge of local history to find potential cross-border consumers in these landscapes.

Our observations and interviews in Tijuana indicate that these urban arrangements indeed reflect a heterogeneous social environment, where differences were more determined by the person's membership to the community than to income disparities. Tijuana appeared to be more socially egalitarian than other Mexican cities, which was attributed to the fact that, being relatively young, it never experienced traditional forms of social and economic relations that were pervasive in the south and centre of the country (Garcia Montaño 1987). This was noted in ethnographies during the 1970s: "The frontier background has contributed to a distinctive character even to the developing of urban cultures in the area. The traditional ascriptive social classes are almost meaningless in the north because of the strength of egalitarianism" (Price 1973, 2). In fact, the people we interviewed shared the view that the gap between rich and poor was not as relevant in the life of the city as the differences between new immigrants and old residents. As they arrived, new comers would establish themselves in separate neighbourhoods, and were seen as 'the other' by those who had lived there longer. Old Tijuana residents distinguished themselves from newcomers, because recent immigrants did not share the habit of crossing the border to shop or visit relatives, and therefore did not partake of the same narratives and frames of reference that old residents shared with those living in 'the other side' ${ }^{8}$.

Hence, when interviewed about how these marketing strategies are developed, the owner of The Weekly Coupon replied that, particularly in Tijuana's old neighbourhoods, they use visual discrimination to determine who is a potential client and who is not. "This is my software", he joked. It involves active and constant scouting, getting into the neighbourhoods on four-wheel-drive vehicles and touring and searching for housing clues that allow marketers to determine who is in a position to be a customer. So market discrimination is done here on a one-to-one basis. The three elements to determine if a household should be included in the database are: entry documents to the U.S., car, and telephone. "We have a first world business that operates in the third world", he said. "And look, because we are catering to our American clients, you have to cross the border to be included, so that will tell you our coupon recipients have to have a passport or a laser visa, which makes us eliminate one quarter of Tijuana. This is because there are a lot of new people from the interior, and you know, they want to work".

\footnotetext{
${ }^{8}$ For the connection between material culture and identity, see Chandra Mukerji (1997, p.21) and Robert Foster (2002).
} 
Interviewer: So their intention is working in the U.S. and they are denied visas?

Marketing business owner: That is right. Yes. Inspections are more thorough. There is a more secure profile, this new terrorism that affects all government.

Interviewer: So this is why they deny visas?

Marketing business owner: Well see, there is now an American database, we don't have access to it, but they know everything. Your entire fiscal life and your whole family is there in that computer, they can follow you, all what you do when you cross, when you come back, all that is being managed now, they control entries and exits in a tremendous way.

Local marketers have not been able to tap into the databases that the U.S. government has built about border crossers. The patterns of movement and individual profiles they look for, though, are similar to those sought by U.S. border enforcement agencies. However, recent developments in Tijuana's urban growth may make it easier, in the future, to gradually incorporate more technical devises to conduct market research in this complex city. Unlike traditional neighbourhoods that have grown throughout the years in a socially mixed fashion, spatial segregation between higher and lower income residents has become more pervasive in the peripheries of the city, with "new settlements led by private investments comprised of similarly priced housing with people of comparable incomes" (Alegría 2006, 353.) Instead of the disorganized neighbourhoods that gradually and chaotically mushroomed throughout the years, these developments are the result of urban planning and have basic infrastructure that includes schools, parks, and other resources (see Escobar 2006). This is not exclusive to Tijuana. These types of developments represent the most successful urban growth model in most Latin American cities (see Cabrales 2002 and López Levi 2008). However, because of its accelerated growth, Tijuana is a leader in housing construction. Although most new housing is built primarily for the middle class, there are also some developments that cater for low-income families, with houses as small as 27.5 meters square (296 square feet) (see Escobar 2006).

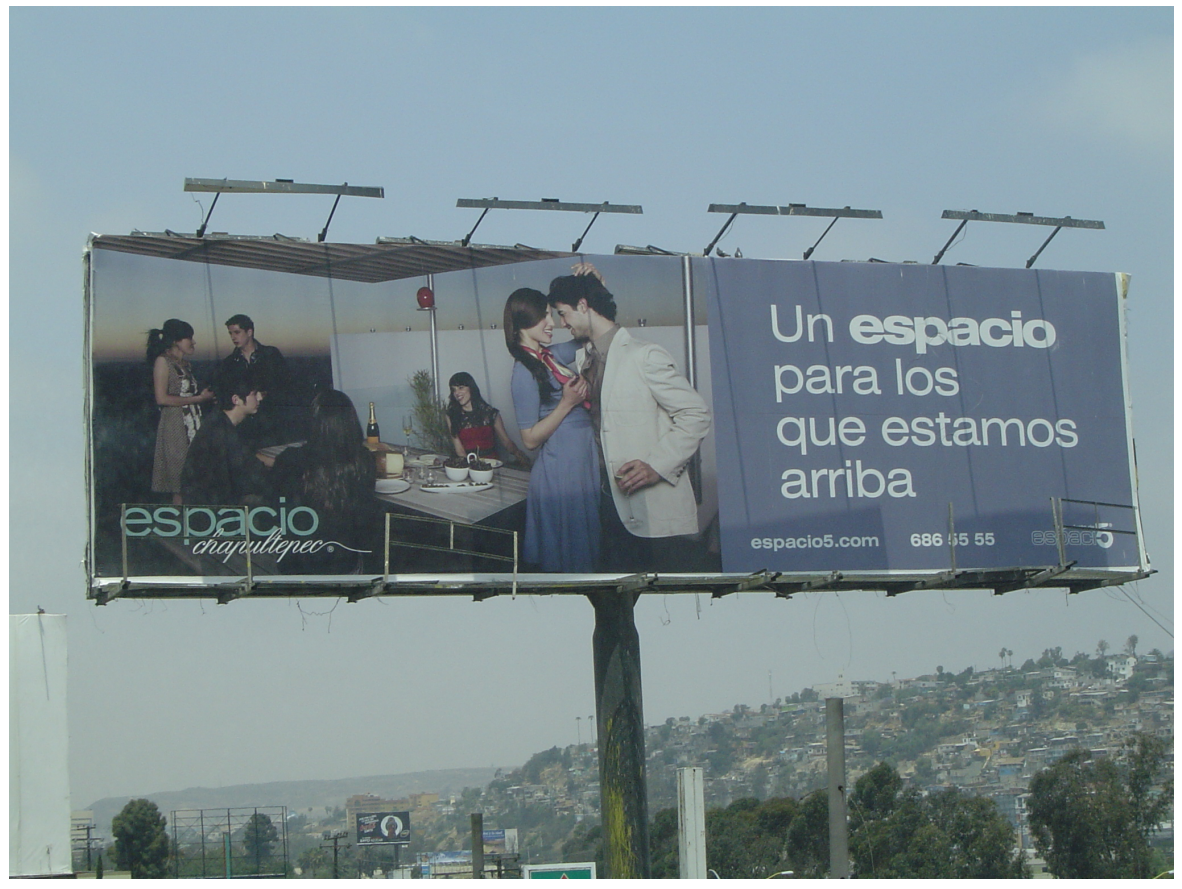

\section{Figure 2}

Finding the yuppie niche: "Espacio 5: A space for those of us on the top".

The different marketing campaigns that advertise this type of housing suggest that developers have effectively identified brackets of income to which potential home-owners belong. Billboards throughout the city contain slogans that emphasize their exclusivity or affordability. Espacio 5 (Space 5), for in- 
stance, is a development of townhouses located to the north of an upscale and prestigious neighbourhood, very popular among sophisticated high income young couples, with a cosmopolitan taste (Figure 2). This development is located on the top of a hill overlooking the U.S.-Mexico border whose ad slogan reads "A Space for those of us at the top". It portrays a group of yuppies having a party at a fancy terrace with a view of the city, making it obvious that 'top' here is not only related to the city's topography, but also its social class pyramid.

For the aspirational middle class, Urbiquinta Versalles caters to desires of opulence and inclusion in what traditional Mexican elitism calls 'gente bien or well off people', with the picture of a little girl, dressed in pink with a matching bow that says: "I am so pretty that I live in Urbiquinta Versalles, only for well off people. And where do you live?" (see figure 3). Similar developments include Tuscan Corner, whose ad has a picture of lined up houses with a Tuscany-like architectural style, with a slogan that says "Live at your level because here, it makes sense to live well" (see figure 4 overleaf). Other projects that obviously cater to people with lower incomes, sometimes emphasize their accessibility and the possibility to finance them, like the case of Real de San Francisco as depicted in figure 5 (overleaf). More than a slogan, this ad shows bullets that make this residential option attractive: "We have the best financing schemes. Everybody qualifies!"

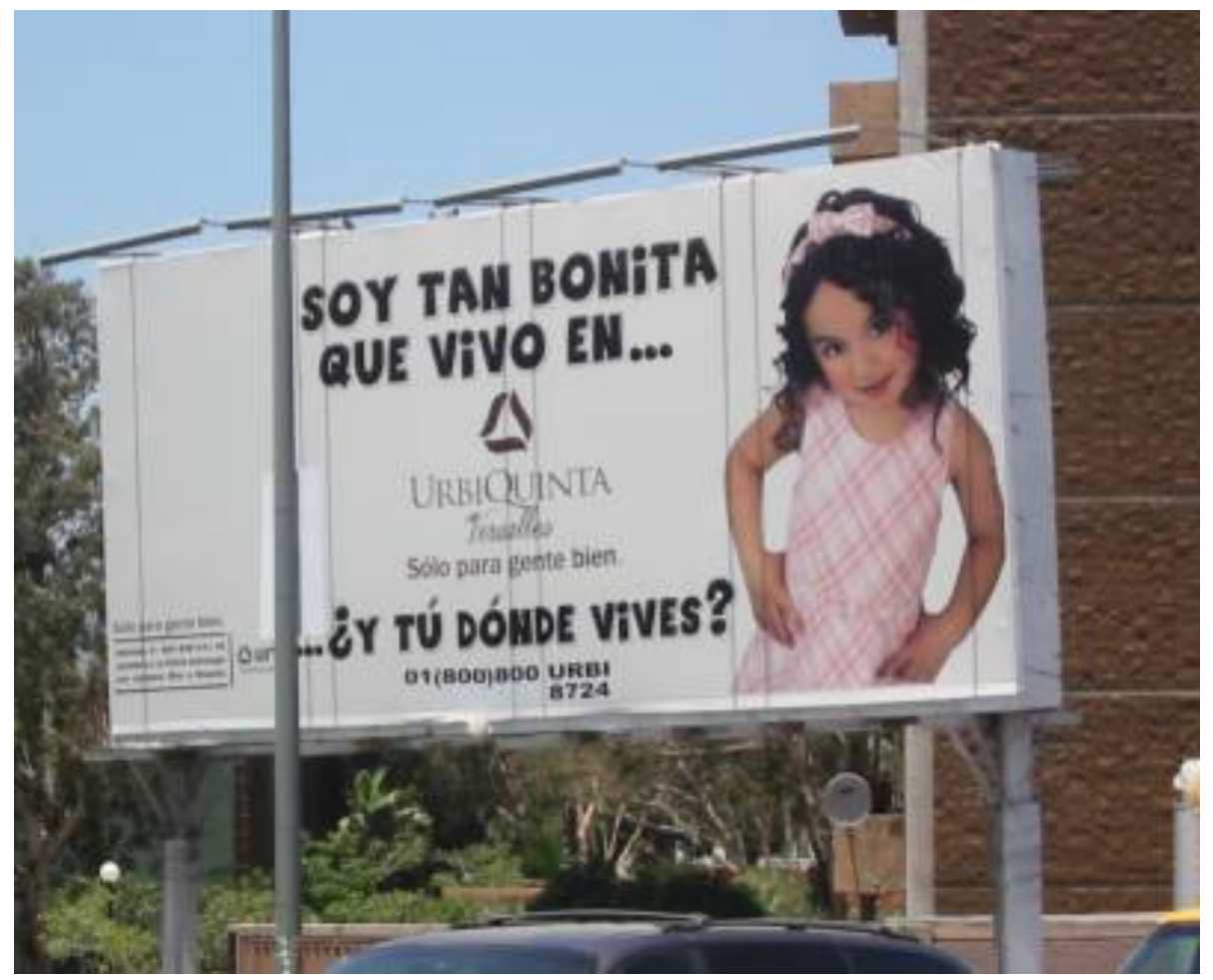

Figure 3.

Marketing middle class housing: "I am so pretty that I live in Urbiquinta Versailles. And where do you live?"

Aside from the undeniable advantage of offering everyone with the possibility of owning a house, this model of urban growth has the capacity to spatially distribute residents in different enclaves, usually gated communities. These communities separate Tijuana's residents according to their income, and in the process, reinforce intra-urban boundaries. This form of urban development is reshaping the geographical landscape of Tijuana into more manageable units, when compared to older parts of the city that were previously organized as irregular settlements (see also Valenzuela Arce 1991, 70-76). Neighbourhoods are partitioned and mapped into discernable orderly brackets. Thus, today's urban dwellers are spatially organized, and therefore, classified and accounted for by developers and Mexican government officials. Both visually and in organizational terms, this represents a modernization of the city, with a 'cleaner' face 
and adequate infrastructure that neatly categorizes people. In other words, new neighbourhoods in Tijuana are undergoing a 'spatial modernization', making urban space easier to fit in a cartographic grid that makes both landscape and people easier to read (Bauman 1998, 33).

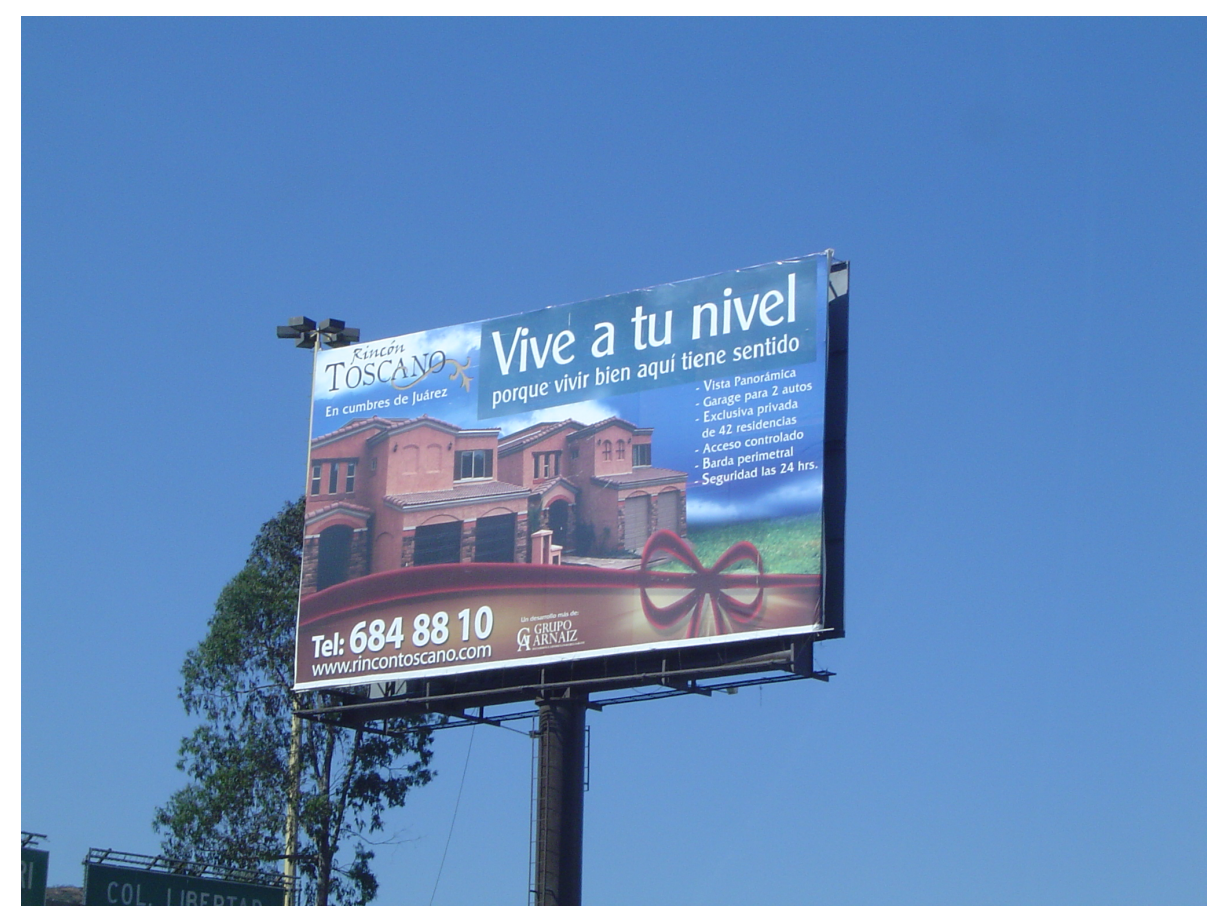

\section{Figure 4}

Live at your

level. Tuscan

Corner

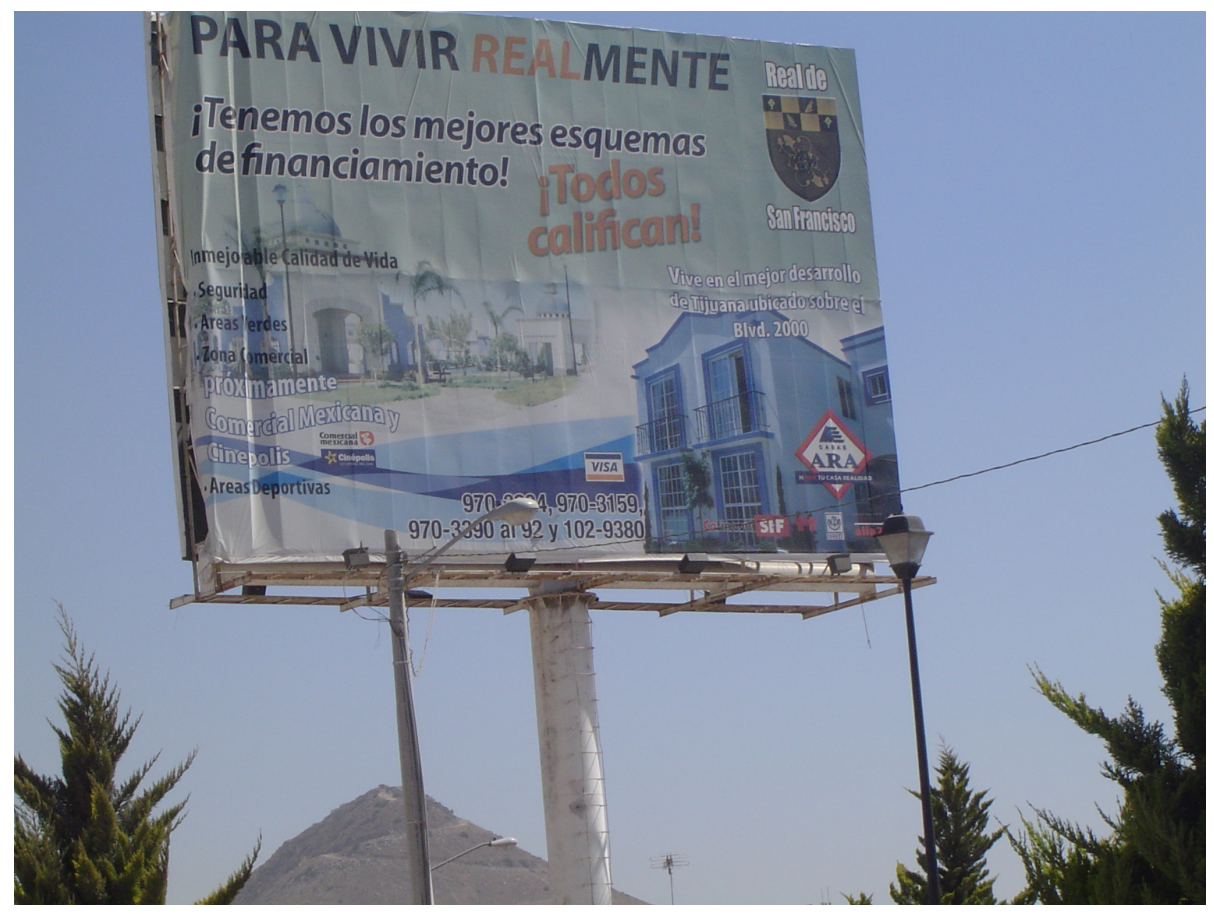

Figure 5

Marketing housing for lower income sectors 
By being more legible, visible, and manageable, Tijuana's new housing developments facilitate the ability for the owners of the Weekly Coupon to identify potential U.S. consumers in Mexican neighbourhoods. Allocations, distributions and attributions will be easier to assign, as the city becomes more legible for administrators, marketers and of course, border enforcement. These new areas allow software and mapping systems to operate effectively, as demographic information about people living there become more susceptible to being included in a database that counts and tracks people's presence. In the context of border enforcement and marketing in Tijuana-San Diego, databases enhance discipline through the conciliation between law and order that Foucault describes (1988). These databases will logistically connect a juridical system that classifies border residents according to their standing in U.S. immigration law, and an administrative system that distributes and segregates people within the territoriality of national boundaries, by monitoring and controlling their patterns of movement. "Whereas the juridical systems" says Foucault, "define juridical subjects according to universal norms, the disciplines characterize, classify, specialize: they distribute along a scale and, if necessary, disqualify and invalidate" (Foucault 1977, 223). Discipline, in this sense, "separates, analyses, differentiates, and carries its procedures of decomposition to the point of necessary and sufficient single units" (Foucault 1977, 170) to make them fit in a database that can potentially track the consumption practices for marketers or patterns of movement for border authorities. In sum, by discussing the marketing strategies of the Weekly Coupon we have shown how binational marketers categorize and identify which populations of borderlanders should be included, excluded, and targeted for the interests of government and economy.

\section{Conclusion}

The U.S.-Mexico border is a region torn by the tensions between economic integration and political sovereignty. In this article, we have argued that these tensions have led, in Tijuana and San Diego, to the compartmentalization and separation of two economic activities that are embedded together into the local economic fabric: consumption and labour. By enforcing this separation, border controls and surveillance technologies that have recently escalated in the Tijuana-San Diego region make it possible to redirect the invisible hand of the market in ways that suit the imperatives of state territoriality. Here, we have discussed the impact of these tensions on Tijuana residents, and how this community has adapted to measures that divide a region historically integrated by patterns of transnational mobility.

We argued that border controls reshaped geographical and social landscapes at the border by reconstructing identities and belonging among local residents, in such a way that income gaps become a source of difference and social stratification among crossers and non-crossers. We have talked about a legal taxonomy that classifies border crossers according to categories of legality that determine whether they are welcome into U.S. territory and with which attributions. Biometric technologies enforce the identification and classification of people involved in this taxonomy by regulating cross-border mobility. Because they enhance population management, these technologies have a disciplinary effect on local residents. However, Tijuanans do not necessarily see themselves according to the categories established by U.S. law. Once it crosses the border into Tijuana, this taxonomy is "remade into the vernacular" (Engle Merry 2000, 219), that is, reframed in order to fit into local experiences. Accordingly, we have demonstrated that the categories established by U.S law to regulate the mobility of border residents are translated in Tijuana as a binary distinction between consumers and workers, which reflects the growing gap between rich and poor in the city.

The distinction between consumers and workers can be observed in the way local marketers design coupon distribution and housing marketing strategies, as they rely on local knowledge to sort and distinguish potential customers. Cross-border marketing also capitalizes on a model of urban growth that socially and spatially segregate people according to income brackets. Socially homogeneous housing developments that become targets of differentiated marketing strategies also facilitate the use of technical devises that make it easier to manage local populations. From interviews with local marketers, and by 
reading closely at marketing texts that advertise housing developments, we have shown how social and spatial segregation across borders and within the city of Tijuana itself ultimately substantiates the distinction between consumers and workers. This distinction establishes a regime at the U.S.-Mexico border where social inequality is increasingly tied with geographical mobility. In Tijuana, people who cross the border with the purpose to work are criminalized, while those who consume are encouraged and protected. Wealthy consumers are attractive for binational marketing and are welcome to engage in crossnational travel, keeping their global connections active and strong (see for example Borja and Castells 1997; Graham and Marvin 2001; Caldeira 2000). Poor workers, in contrast, are becoming part of an "immobilized 'global underclass" (Pickering and Weber 2006, 8) considered undesirable by border enforcement and irrelevant for marketing agencies, and are becoming increasingly isolated, disconnected, and territorially constrained.

\section{References}

Ackleson, Jason. 2000. Discourses of Territoriality and Identity on the U.S.-Mexico border. In Geopolitics at the End of the Twentieth Century. The Changing World Political Map, eds Nurit Kliot and David Newman, 155-179. London: Frank Cass.

2003. Securing Through Technology? 'Smart Borders' after September 11. Knowledge, Technology and Policy 16(1): 56-74.

Acuña, Beatriz. 1988. Transmigración legal en la frontera México-Estados Unidos. Revista Mexicana de Sociología 50(4): $277-$ 322.

Alegría, Tito. 2002. Demand and Supply of Mexican Cross-Border Workers. Journal of Borderlands Studies 17(1): 37-55. . 2006. Urban Structure and Social Segregation in Tijuana. In Equity and Sustainable Development. Reflections from the U.S.-Mexico Border, eds Jane Cough-Riquelme and Nora Bringas. San Diego: Center for U.S.-Mexican Studies, UCSD

Amoore, Louise. 2006. Biometric borders: Governing mobilities in the war on terror. Political Geography 25: 336-351. 2007. Vigilant Visualities: The Watchful Politics of the War on Terror. Security Dialogue 38: 215-351.

., Stephen Marmura and Mark Salter. 2008. Smart Borders and Mobilities: Spaces, Zones, Enclosures. Surveillance \& Society 5(2): 96-101.

Andreas, Peter. 1996. U.S.-Mexico: Open Markets, Closed Border. Foreign Policy 103(Summer): 51-69. 2000. Border Games. Policing the U.S.-Mexico Divide. Cornell: University Press.

Bauman, Zygmunt. 1998. Globalization. The Consequence. New York: Columbia University Press.

Borja, Jordi and Manuel Castells. 1997. Local and Global. The Management of Cities in the Information Age. London: Earthscan Publications.

Bourdieu, Pierre. 1980. The Logic of Practice. Stanford: University Press.

Cabrales, Luis Felipe. 2002. Latinoamérica: Países abiertos, ciudades cerradas. Guadalajara: Universidad de Guadalajara and UNESCO.

Caldeira, Teresa. 2000. City of Walls. Crime, Segregation and Citizenship in Sao Paolo. Berkeley and Los Angeles: University of California Press.

Chávez, Sergio. 2007. The Making of a Border Labor Migration System: Government Policies, Labor Markets, and Social Networks in Tijuana. PhD thesis, Cornell University.

- (Forthcoming). Navigating the U.S.-Mexico Border: The Crossing Strategies of Undocumented Workers in Tijuana, Mexico. Ethnic and Racial Studies, Special Issue: Undocumented Migrants: Policy, Politics, and Everyday Lives, Eds. Alice Bloch and Milena Chimienti.

Cornelius, Wayne. 2005. Controlling 'Unwanted' Immigration: Lessons from the United States, 1993-2004. Journal of Ethnic and Migration Studies 31(4): 775-94.

Crossborder Business Associates (CBA). 2004. Hispanic Marketing at La Frontera. Power Point Presentation, 2004.

De Laet, Debra. 2000. U.S. Immigration Policy in an Age of Rights. Westport CT: Praeger.

Delaney, David. 2005. Territory. A Short Introduction. Oxford: Blackwell.

Donato, Katharine, Brandon Wagner, and Evelyn Patterson. 2008. The Cat and Mouse Game at the Mexico-U.S. Border: Gendered Patterns and Recent Shifts. International Migration Review 42(2): 330-59.

Engle Merry, Sally. 2006. Human Rights and Gender Violence. Translating International Law into Local Justice. Chicago: Chicago University Press.

Escobar, Miguel. 2006. Housing in Tijuana: A Dichotomy of Land and Space. Worldview. Perspectives on Architecture and Urbanism From Around the Globe. [Online]. http://www.worldviewcities.org/tijuana/housing.html [Accessed 24/01/2006].

Foster, Robert. 2002. Materializing the Nation. Commodities, Consumption and Media in Papua New Guinea. Indiana: Indiana University Press.

Foucault, Michel. 1977. Discipline and Punishment. New York: Pantheon. 
1988. The Political Technology of Individuals. In Technologies of the Self. A Seminar With Michel Foucault, eds Luther Martin et al., 145-162. Boston: MIT Press.

1991. Governmentality. In The Foucault Effect. Studies on Governmentality, eds Graham Burchell, Colin Gordon and Peter Miller, chap. 4. London: Harvester Wheatsheaf.

Fussell, Elizabeth. 2004. Sources of Mexico's Migration Stream: Rural, Urban, and Border Migrants to the United States. Social Forces 82(3): 937-67.

Ganster, Paul and David Lorey. 2008. The US-Mexican border into the twenty-first Century. Lanham: Rowman and Littlefield Pubs.

García Montaño, Jorge. 1987. Diagnóstico de Largo Plazo de la Economía de Baja California. 1950-1980. Cuadernos de Economía 4(3). Universidad de Baja California.

Gathmann, Christina. 2008. Effects of Enforcement on Illegal Markets: Evidence from Migrant Smuggling Along the Southwestern Border. Journal of Public Economics 92: 1926-41.

Ghoddar, Suad and Gynthia Brown. 2005a. The Cross-Border Mexican Shopper: A Profile. Research Review 12(2): 46-50.

- 2005b. The Economic Impact of Mexican Visitors Along the U.S.-Mexico Border: A Research Synthesis. International Council of Shopping Centers Working Paper Series.

Graham, Stephen and Simon Marvin. 2001. Splintering Urbanism. London: Routledge.

Hastings, Donnan and Thomas M. Wilson. 1999. Borders: Frontiers of Identity, Nation and State. Oxford: Berg.

Hernández-León, Rubén. 2008. Metropolitan Migrants: The Migration of Urban Mexicans to the United States. Berkeley: University of California Press.

Herzog, Lawrence Arthur. 1990. Where North Meets South: Cities, Space, and Politics on the U.S.-Mexico Border. Austin, TX: Center for Mexican American Studies, University of Texas at Austin.

Heyman, Josiah. 2002. U.S. Immigration Officers of Mexican Ancestry as Mexican Americans, Citizens, and Immigration Police. Current Anthropology 43(3): 479-507.

2009. Trust, Privilege, and Discretion in the Governance of the US Borderlands with Mexico. Canadian Journal of Law and Society 24(3): 367-90.

Lewis, Lewis. 2005. Expanding Surveillance: Connecting Biometric Information Systems to International Police cooperation. In Global Surveillance and Policing. Borders, Security Identity, eds Elia Zureik and Mark Slater. Cullompton: Willan.

López Levi, Liliana. 2008. Utopias and Dystopias Residential in Mexico, Atelier Geográfico. Revista Electrónica 2(3): 1-17. [Online] http://www.revistas.ufg.br/index.php/atelie/article/viewFile/3900/3584 [Accessed 27/02/2009].

Lyon, David. 2005. The Border is Everywhere: ID Cards, Surveillance and the Other. In Global Surveillance and Policing. Borders, Security Identity, eds Elia Zureik and Mark Slater, ch. 5. Cullompton: Willan.

Martínez, Mariana. 2006. Gastan Tijuanenses 5,900 mdd en S.D. Frontera (Tijuana), October 19, 2006 edition.

Martínez, Oscar. 1994. Border People, Life and Society in the U.S.-Mexico Borderlands. Tucson: University of Arizona Press.

Martis, Kenneth Charles. 1970. United States International Land Border crossings. San Ysidro, CA. MA Thesis, San Diego State College.

Muller, Benjamin. 2004. (Dis)Qualified Bodies: Securitization, Citizenship and 'Identity Management'. Citizenship Studies 8(3): 279-294.

2008. Securing the Political Imagination: Popular Culture, The Security Dispositif and the Biometric State. Security Dialogue 39(2-3): 199-220.

Murià, Magalí and Teófilo Chávez. 2006. Cómo vemos a nuestros vecinos del norte? Apuntes sobre la representación de San Diego en la prensa de Tijuana. Comunicación y Sociedad, no. 6: 37-57.

Mukerji, Chandra. 1983. From Graven Images. Patterns of modern materialism. New York: Columbia University Press. . 1997. Territorial Ambitions and the Gardens of Versailles. Cambridge: Cambridge University Press.

Musbach, James. 1980. Binational Retailing in San Ysidro, California. A Report to the Office of Economic Development, County of San Diego, May 1980.

Nevins, Joseph. 2000. The remaking of the California-Mexico Boundary in the Age of NAFTA. In The Wall Around the West, eds Peter Andreas and Timothy Snyder, chap. 6. Lanham MD: Rowman \& Littlefield.

2002. Operation Gatekeeper. The rise of the "illegal alien" and the making of the U.S-Mexico boundary. New York: Routledge.

Payan, Tony. 2006. The Three U.S.-Mexico Border Wars. Drugs, Immigration and Homeland Security. Westport CT: Praeger Security International.

Paasi, Anssi. 1996. Territories, Boundaries and Consciousness: The Changing Geographies of the Finnish-Russian Border. Chichester and New York: Wiley \& Sons.

1999. Boundaries as Social Processes: Territoriality in the World of Flows. In Boundaries, Territory and Post-modernity, ed. David Newman, 69-88. Abingdon, Oxon: Frank Cass.

Pickering, Sharon and Leanne Weber. 2006. Borders, Mobility and Technologies of Control, Dordrecht: Springer.

Price, John. 1973. Tijuana: Urbanization in a Border Culture, Notre Dame: University of Notre Dame Press.

Profitt, Dennis. 1988. The Symbiotic Frontier. The Emergence of Tijuana since 1769. PhD thesis, UCLA.

Rubin-Kurtzman, Jane R., Roberto Ham-Chande and Maurice D. Van Arsdol Jr. 1996. Population in Trans-Border Regions: The Southern California-Baja California Urban System. International Migration Review 30(4): 1020-45.

Sack, Robert. 1986. Human Territoriality. Cambridge: Cambridge University Press.

1992. Place, Modernity and the Consumer's World. Baltimore: John Hopkins University Press. 
San Diego Association of Governments (SANDAG) and California Department of Transportation District 11. 2006. Economic Impacts of Wait Times at the San Diego-Baja California Border. Final Report, San Diego, California, January 19, 2006. San Diego Dialogue. 1994. Who Crosses the Border. A view of the San Diego/Tijuana Metropolitan Region. A Report of San Diego Dialogue, University of California San Diego.

Sassen, Saskia. 1996. Losing Control? Sovereignty in an age of Globalization, New York: Columbia, 1996

Shields, Rob. 1991. Places on the Margin. Alternative Geographies of Modernity. London and New York: Routledge.

Spener, David. 2009. Clandestine Crossings: Migrants and Coyotes on the Texas-Mexico Border. Ithaca: Cornell University Press.

Singer, Audrey and Douglas S. Massey. 1998. The Social Process of Undocumented Border Crossing among Mexican Migrants. International Migration Review 32(3): 561-92.

Sorensen, Georg. 2004. The Transformation of the State. Beyond the Myth of Retreat. New York: Palgrave Macmillan.

Star, Susan Leigh and Geoffrey C. Bowker. 1999. Sorting Things Out. Cambridge MA: MIT Press.

Torpey, John. 2000. The Invention of the Passport. Surveillance, Citizenship and the State, Cambridge and New York: Cambridge University Press.

Tuathail, Gearóid. 2000. Borderless Worlds? Problematising Discourses of Discourses of Deterritorialization. In Geopolitics at the End of the twentieth century: the changing world political map, eds Nurit Kliot and David Newman, 139-154. London: Frank Cass.

U.S. Department of State. 2008. Adjusted Refusal Rate - B Visas Only. [Online] http://travel.state.gov/pdf/FY07.pdf [Accessed 28/04/2008].

Valenzuela Arce, Jose Manuel. 1991. Empapados de Sereno: Reconstrucción testimonial del movimiento urbano popular en Baja Califronia (1928-1988), El Colegio de La Frontera Norte, Tijuana, Baja California.

Van der Ploeg, Irma. 2006. Borderline Identities: The Enrollment of Bodies in the Technological Reconstruction of Borders. In Surveillance and Security. Technological Politics and Power in Everyday Life, ed. Torin Monahan, chap. 11. New York: Routledge.

Wonders, Nancy. 2006. Global Flows, Semi-Permeable Borders and New Channels of Inequality. Border Crossers and Border Performativity. In Borders, Mobility and Technologies of Control, eds Sharon Pickering and Leanne Weber, 63-86. Dordrecht: Springer. 